\title{
PROSTORSKI VIDIKI RAZVOJA KMETIJ
}

\author{
Anton Perpar, Matija Kovačič \\ Katedra za agrarno ekonomiko, ruralno sociologijo in razvoj podeželja \\ Oddelek za agronomijo Biotehniške fakultete Univerze v Ljubljani \\ Jamnikarjeva I0I, SI - 1000 Ljubljana, Slovenija \\ e-mail: anton.perpar@bf.uni-lj.si; matija.kovacic@bf.uni-lj.si
}

Izvirni znanstveni članek

COBISS 1.01

\section{Izvleček}

Kmetijstvo na podeželju danes ni ne edina in tudi ne več prevladujoča dejavnost. Neupoštevanje posebnosti kmetijstva povzroča predvsem naslednje težave: zmanjševanje obsega pridelovalnih zemljišč najboljše kakovosti, prostorsko utesnjevanje kmetij v naseljih ter ovirane prometne povezave med kmetijami in njihovi pridelovalnimi površinami. Številne kmetije so zaradi teh vzrokov kljub razvojnim ambicijam omejevane ali ovirane pri nadaljnjem razvoju. Kot posledice se $\mathrm{v}$ podeželskih naseljih pojavljajo socialne napetosti, izginja agrarna identiteta podeželskih naselij ter krajine, med mladimi pa je vse manj interesa za kmetovanje.

Ključne besede: kmetijstvo, podeželje, prostorsko načrtovanje, kmetijska zemljišča, razvoj kmetij, Slovenija

\section{SPATIAL ASPECTS OF FARM DEVELOPMENT}

\begin{abstract}
Nowadays agriculture is not the only even not a dominant activity in the countryside. Unconsidered agriculture in the processes of spatial planning cause different problems to farms, such as decrease in the extent of best quality agricultural land, spatial tightening of farms in rural settlements and obstructed traffic connections between farms and their production areas. As a result many farms are limited or obstructed in their future development. As a consequence social tensions appear, rural identity of settlements and agricultural landscape disappears and there is less and less interest in farming under young people.
\end{abstract}

Key words: agriculture, rural areas, spatial planning, agricultural land, farm development, Slovenia 


\section{UVOD}

Kmetijstvo se pri prostorskem načrtovanju v Sloveniji praviloma ne obravnava kot specifično področje ali kot subjekt načrtovanja. Kmetijski pridelovalni prostor je pretežno obravnavan kot odprt ali celo kot prazen prostor, ki je praviloma brez posebnih omejitev na voljo za gradbene posege $\mathrm{v}$ prostor. Zakonske omejitve za spreminjanje namembnosti najboljših kmetijskih zemljišč niso bile posebno učinkovite in so bile celo močno reducirane, prisotne pa so celo močne težnje po njihovi popolni odpravi. Kmetijstvo ni obravnavano kot druge dejavnosti v prostoru, ki imajo možnost preprečiti posege na prostor, ki ga zasedajo s svojo dejavnostjo, oziroma možnost določati pogoje za posege v prostor, ki je v njihovem interesnem območju, z izdajanjem soglasja k nameravanim posegom. Kmetijstvo in kmetijska gospodarstva so praktično obravnavana kot dejavnost, ki le začasno zaseda prostor in jih je za potrebe drugih dejavnosti praktično kadarkoli mogoče odstraniti iz določenega območja.

Stanje je deloma pogojeno z naravo kmetijske dejavnosti. Ta namreč prostora ne zaseda trajno (razen objektov, ki so povezani s kmetovanjem) in ne povzroča trajnih sprememb v strukturi površja. Poleg tega kmetijstvo v naših razmerah uporablja praktično celoten odprt prostor. Novih (nekmetijskih) zemljišč, ki bi bila brez velikih agromelioracijskih posegov primerna za kmetijsko dejavnost pri nas ni na voljo, oziroma so ta pod ostrim naravovarstvenim režimom.

Drugi dejavnik, ki pogojuje opisano stanje je metodologija prostorskega načrtovanja, ki tudi na podeželju uporablja pristope načrtovanja urbanih naselij. Pri tem ne upošteva posebnosti ruralnih naselij, ali natančneje agrarnih naselij, kar podeželska naselja v svoji zasnovi so. $\mathrm{V}$ sodobnem razvoju podeželja in tudi kmetijstva sicer mnoga kmetijska gospodarstva izgubljajo agrarno funkcijo in podeželska naselja privzemajo tudi neagrarne funkcije. Kljub temu pa bi bilo potrebno načrtovanje podeželskih naselij prilagoditi njihovim posebnostim in funkcijam, ki so drugačne in zahtevajo drugačen pristop kot v urbanih naseljih. Agrarna funkcija podeželskih naselij ostaja odločilni kriterij urejanja vse dotlej, dokler se v podeželskih naseljih izvaja kmetijska dejavnost, čeprav je zaradi strukturnih sprememb (procesa odmiranja kmetij in po drugi strani večanja preostalih kmetij) vse manj gospodinjstev, ki se ukvarjajo s kmetovanjem.

$\mathrm{V}$ dosedanjem načinu načrtovanja razvoja in urejanja podeželskih naselij lahko zaznavamo naslednje skupine težav, ki otežujejo ali ovirajo razvoj kmetijstva in kmetijskih gospodarstev:

- $\quad$ zmanjševanje pridelovalnih potencialov (zemljišč) kmetijstva,

- prostorsko utesnjevanje kmetij,

- $\quad$ prekinjanje neposredne prometne povezanosti kmetij z njihovimi zemljišči,

- $\quad$ omejenost in oviranje razvoja kmetij,

dodatno kot posledica pa:

- $\quad$ socialne napetosti v podeželskih sredinah,

- $\quad$ izginjanje agrarne identitete podeželskih naselij in krajine ter

- $\quad$ zmanjšan interes mladih za kmetovanje. 


\section{METODOLOGIJA}

Problematika, ki jo v prispevku obravnavamo, ni bila sistematično obdelana v sklopu neke raziskave, saj za tovrstne raziskave doslej še ni bilo interesa. Problematiki je premalo pozornosti namenjalo tudi kmetijstvo samo. Primere in težave kmetij, ki se pojavljajo v prostoru, smo evidentirali pri delu na terenu in v lokalnih okoljih pri pripravi programov in strategij razvoja kmetijstva, dopolnilnih dejavnosti in celostnega razvoja podeželja. V prispevku torej ne gre za celovit pregled prostorske problematike kmetij, pač pa za predstavitev posameznih vidikov $\mathrm{z}$ namenom opozoriti na aktualnost tematike in na potrebo po sistematičnem raziskovanju te problematike.

\section{PROSTORSKI PROBLEMI V POVEZAVI Z RAZVOJEM KMETIJSTVA IN KMETIJSKIH GOSPODARSTEV}

\section{I Zmanjševanje proizvodnih potencialov kmetijstva}

Gledano iz zgodovinske retrospektive so naselja v našem prostoru praviloma nastala na slabših zemljiščih, vendar v neposredni bližini kompleksov najboljših kmetijskih zemljišč. Izjema so naselja v obsežnejših plodnih ravnicah, kjer slabših zemljišč za lokacijo naselja ni bilo v racionalni bližini. Ta izjemno racionalen pristop je v kasnejšem razvoju omogočil, da se naselja, tako mestna kot podeželska, širijo na najboljša kmetijska zemljišča in to celo tam, kjer je v zaledju naselja na voljo dovolj slabših zemljišč. Pri tem seveda igra odločilno vlogo trenutni strošek gradnje, ki pa ne zajema »oportunitetnega stroška « ${ }^{1}$, ki izhaja iz dejstva, da kmetijska panoga (in s tem nacionalno gospodarstvo kot celota), na pozidanem zemljišču trajno izgubi možnost pridelovanja hrane oziroma ustvarjanja dohodka. V naših razmerah je jedro problema $v$ tem, da nimamo na voljo zemljišč, ki bi jih bilo mogoče kultivirati in usposobiti za kvalitetna kmetijska zemljišča in s tem nadomestiti $\mathrm{z}$ urbanizacijo izgubljena najboljša kmetijska zemljišča.

Kmetijska pridelava v Sloveniji se zmanjšuje, ker se zmanjšujejo tudi proizvodni potenciali kmetijstva. Leta 1900 je bilo v Sloveniji 1.102 .900 ha kmetijskih zemljišč $(54,4 \%$ vseh zemljišč), leta 19501.054 .600 ha (52\%), leta 1996 pa le še 781.000 ha ali $38,6 \%$ vseh zemljišč (Perpar in Kovačič 2006, 82). Po zadnjih ocenah Slovenija pridela samo še okrog $60 \%$ potrebne hrane, kar je posledica:

- $\quad$ intenzivnega zaraščanja slabših in razdrobljenih kmetijskih zemljišč, neprimernih za strojno obdelavo ter

- intenzivne in prostorsko potratne urbanizacije, zlasti v primestnih podeželskih območjih, ki praviloma posega na najboljša kmetijska zemljišča.

\footnotetext{
1 Oportunitetni strošek predstavlja vrednost alternative, ki je nismo izbrali oz. korist, ki jo žrtvujemo; donos, ki se mu odpovemo (Rebernik 1997, 17).
} 
Analiza širjenja pozidanih zemljišč v Ljubljanski urbani regiji v obdobju od 1951-2002 (Cof 2005, 27) je na primer pokazala, da je bilo v obdobju 1951-1975 dobrih 78\% vseh pozidav umeščenih na najboljša kmetijska zemljišča. Kljub predpisom o varstvu najboljših kmetijskih zemljišč pred spremembo namembnosti se je v obdobju 1985-2002 ta delež zmanjšal le na $72 \%$.

Na zaskrbljujoče zmanjševanje obdelovalnih kmetijskih zemljišč v Sloveniji kaže tudi analiza podatkov za zadnjih petdeset let. Po grobi oceni potrebujejo države v našem geo-klimatskem pasu za zagotovitev potrebnih količin hrane okrog $3.000 \mathrm{~m}^{2}$ obdelovalnih kmetijskih zemljišč (njiv, travnikov in sadovnjakov) na prebivalca. Od leta 1950 do leta 2000 se je ta površina v Sloveniji s $3.873 \mathrm{~m}^{2}$ zmanjšala na $2995 \mathrm{~m}^{2}$ na prebivalca. V istem času se je površina njiv in vrtov, kot najkvalitetnejših pridelovalnih zemljišč, razpolovila $\left(\mathrm{z} 2.102 \mathrm{~m}^{2}\right.$ na $1.118 \mathrm{~m}^{2}$ na prebivalca), razpolovila pa se je tudi površina vseh kmetijskih zemljišč v državi (s $6.695 \mathrm{~m}^{2}$ na $3.542 \mathrm{~m}^{2}$ na prebivalca). Če bi se dosedanji trendi nadaljevali, bi v Sloveniji teoretično čez 111 let ostali brez obdelovalnih kmetijskih zemljišč, brez njiv pa že čez 57 let! Tudi danes so trendi spreminjanja namembnosti kmetijskih zemljišč v občutnem porastu (Predlog dopolnitve Zakona o kmetijskih zemljiščih, 2006).

Glede na načrtovani dolgoročni razvoj kmetijstva ter na postopno izločanje pridelovalnih tehnologij, ki niso okolju prijazne, bi morali v Sloveniji trajno varovati tako rekoč vsa kmetijska zemljišča. To potrjuje tudi majhen obseg kmetijskih površin na prebivalca, ki je že sedaj med najmanjšimi v Evropi. Če upoštevamo podatke o površini njiv in vrtov v uporabi iz popisa kmetijstva 2000, potem premoremo na prebivalca v Sloveniji le še 0,0864 ha oziroma $864 \mathrm{~m}^{2}$ njiv in vrtov (v letu 1992 še 0,09 ha/preb.). V istem času je imela Velika Britanija 0,112 ha/ preb., Belgija 0,095 ha/preb., Nizozemska in Švica pa le 0,060 ha/preb. (Predlog dopolnitve Zakona o kmetijskih zemljiščih, 2006).

Tudi obstoječa Strategija razvoja slovenskega kmetijstva upošteva več razvojnih scenarijev. Ob upoštevanju scenarija, ki zagotavlja dokaj uravnoteženo prehransko bilanco ob zagotavljanju obdelave vse razpoložljive kmetijske zemlje, ekološko sprejemljivih tehnologij in pridelovanja kakovostne hrane za vse prebivalce, bi za to potrebovali 799.000 ha aktivne kmetijske zemlje (Strategija razvoja slovenskega kmetijstva, 1993), kar je več, kot je bilo v preteklosti za kmetijsko rabo razvrščene v prostorskih planih občin in države. Ta podatek kaže na resnost razmer in na realne možnosti za zagotavljanje prehranske varnosti Slovenije.

Tudi podatki o predlogih občin za spremembo namembnosti najboljših kmetijskih zemljišč v Sloveniji v zadnjih letih kažejo na negativen odnos do varstva kmetijskih zemljišč (v letu 1996 npr. 224 ha, v letu 2002 pa kar 2384 ha). Pri tem je potrebno poudariti, da večina posegov ni namenjena dejavnostim, ki bi prispevale h gospodarskemu razvoju občin, ampak gre pretežno za individualno, pogosto v prostoru razpršeno stanovanjsko gradnjo (Predlog dopolnitve Zakona o kmetijskih zemljiščih, 2006).

Zmanjševanje površine najboljših kmetijskih zemljišč, kar se dogaja predvsem v ravninskih območjih, je torej resna ovira za učinkovito izboljšanje agrarne strukture in $\mathrm{s}$ tem izboljšanje konkurenčnosti slovenskega kmetijstva. Dodatno k temu prispeva še interes lastnikov kmetijskih zemljišč v zaledju naselij, da njihova zemljišča v procesu prostorskega načrtovanja dobijo status zazidljivih zemljišč, s čemer močno naraste njihova tržna vrednost. 
Da bi izboljšali stanje in zmanjšali trend pozidavanja najboljših kmetijskih zemljišč, bi bilo potrebno dopolniti in dosledno izvajati kmetijsko zemljiško politiko. Potrebno bi bilo zlasti:

- natančneje definirati najboljša kmetijska zemljišča in jih prostorsko opredeliti,

- $\quad$ šritev naselij usmerjati izključno na prostor z manj kvalitetnimi zemljišči ali v gozd; naselij, ki takih zemljišč v svojem zaledju nimajo, pa naj ne bi širili z bivalnimi objekti oziroma objekti za nekmetijske dejavnosti,

- $\quad$ uporabo najboljših kmetijskih zemljišč za pozidavo omejiti samo na neizogibne primere povezane z izgradnjo prometne, komunalne in družbene infrastrukture,

- del rente (vrednosti), ki jo zemljišče pridobi s spremembo namembnosti (ko postane zazidljivo) preusmeriti v izboljševanje preostalih kmetijskih zemljišč,

- $\quad$ kar se da omejiti prehajanje najboljših kmetijskih zemljišč v last nekmetov,

- $\quad$ vzpostaviti nadzor (evidence) nad prometom s kmetijskimi zemljišči.

\subsection{Prostorsko utesnjevanje kmetij}

O prostorski utesnjenosti kmetij govorimo takrat, kadar te na obstoječi lokaciji ne morejo več povečati svojih gospodarskih objektov, da bi posodobili ali razširili svojo dejavnost, ali povečati oziroma primerno urediti funkcionalnega prostora na svojem gospodarstvu, ki ga zahteva uporaba sodobne strojne opreme.

Kmetije, ki so locirane v naseljih, so pogosto prostorsko utesnjene, ali pa to postanejo z izgradnjo novih objektov v njihovi neposredni soseščini. Vzroki za to so:

- $\quad$ majhen obseg zemljišča na obstoječi lokaciji kmetije,

- $\quad$ lastniki (praviloma starejša generacija) zemljišča $v$ neposredni soseščini kmečkega obrata prodajo oziroma podarijo kot del dediščine potomcem, ki ne kmetujejo. Ta proces spodbuja tudi prostorsko načrtovalska praksa, ki takšna zemljišča praviloma vključuje v zazidljiva območja, oziroma objekte, ki so bili na takih lokacijah zgrajeni na črno, razmeroma enostavno legalizira.

Poseben problem je, kadar želi kmetija, ki je prostorsko utesnjena, povečati obseg svoje dejavnosti in bi morala zato povečati tudi objekte in funkcionalni prostor na svojem gospodarskem dvorišču. V takih primerih je nujna preselitev kmetije na rob naselja, kar pa je zaradi visokih stroškov le skrajna možnost.

$\mathrm{V}$ tem kontekstu je problematično tudi vključevanje aktivnih kmetijskih zemljišč v zazidljiva območja naselij zaradi načela zaokroževanja območij in zgoščevanja poselitve. Pogosto gre za kakovostna zemljišča vitalnih kmetij, ki tvorijo z gospodarskim dvoriščem kmetije zaokrožen kompleks. Širjenje podeželskih naselij načrtovalci pogosto usmerjajo tudi na zemljišča, ki ležijo ob kompleksih proizvodnih zemljišč kmetij na obrobju naselja, ali so celo v lasti teh kmetij. $Z$ zazidavo teh zemljišč bi bil prizadetim kmetijam praktično onemogočen nadaljnji obstoj.

Pri ukrepih za izboljšanje stanja je potrebno:

- dosledno upoštevati varovanje najboljših kmetijskih zemljišč pred spremembo namembnosti in razvoj naselij usmerjati na slabša zemljišča oz. gozd, 
- pri prostorskem načrtovanju podeželskih naselij predvideti prostor za umestitev kmetij, ki se morajo izseliti iz naselja,

- $\quad$ v predpisih o urejanju prostora predvideti preverjanje interesa oz. potrebe kmetij za širjenje na obstoječih lokacijah oziroma pridobitev soglasja s strani obstoječih kmetij za novogradnje $v$ njihovi neposredni soseščini,

- $\quad$ kmetijska zemljišča, ki tvorijo z gospodarskim obratom vitalnih kmetij zaokrožen kompleks, je treba ohraniti za trajno kmetijsko rabo, tudi če so znotraj zazidljivih območij naselij.

\subsection{Prometno utesnjevanje kmetij}

O prometni utesnjenosti kmetij govorimo, kadar imajo te močno otežen dostop do svojih proizvodnih zemljišč zaradi izgradnje nove prometne infrastrukture ali povečanja prometa na obstoječi prometni mreži, ki je posledica zgostitve pozidave. $V$ praksi se to pogosto dogaja:

- $\quad$ z izgradnjo obvoznic (primer naselja Bitnje),

- $\quad$ z izgradnjo novih stanovanjskih sosesk ob obstoječi lokalni, pogosto celo poljski prometni mreži, ki postane glavna prometnica v naselju.

Ker so kmetije tudi v takih primerih prisiljene uporabljati javno cestno infrastrukturo, se pojavljajo problemi kot so:

- upočasnitev oziroma oviranje prometa zaradi prisotnosti kmetijskih strojev na cestah, saj se ti ne morejo premikati z običajnimi hitrostmi in so pogosto tudi širših dimenzij,

- onesnaževanje javnih prometnic z blatom, ki ga kmetijski stroji prinašajo s kmetijskih površin.

Kmetije se tako ne morejo izogniti kršitvam prometnih predpisov in povečani nevarnosti povzročanja prometnih nesreč, in s tem stroškov, ki jih to potegne za sabo.

Ukrepi za izboljšanje stanja:

- $\quad$ pri gradnji prometne infrastrukture v podeželskih naseljih, pa tudi pri širjenju podeželskih naselij, je treba upoštevati posebne prometne pogoje oziroma zahteve, ki so vezani na obdelovanje zemlje.

- $\quad$ posege $\mathrm{v}$ prostor je treba načrtovati tako, da kmetovanje ne bo ovirano, kmetje pa zaradi njih ne bodo imeli dodatnih stroškov oz. ne bodo izpostavljeni dodatnim nevarnostim.

- obstoječe kritične točke je potrebno postopno sanirati po vzorih iz nekaterih zahodnoevropskih držav (npr. posebne obvozne poti za kmetijsko mehanizacijo, tlakovanje ali celo asfaltiranje kolovozov poljskih poti v segmentu, ko se priključijo javni prometnici, ureditev potrebne prometne signalizacije ipd.).

\subsection{Socialne napetosti in izginjanje agrarne identitete podeželskih naselij ter kmetijske krajine in zmanjšan interes mladih za kmetovanje}

Struktura prebivalstva na podeželju se spreminja: izboljšuje se poklicna sestava, zmanjšuje se delež kmečkega prebivalstva in število kmetij, vasi dobivajo nove priseljence in 
nove dejavnosti. Večina teh značilnosti je pozitivna, saj prinaša nove razvojne impulze, nove izzive in možnosti. Vse spremembe pa hkrati vplivajo tudi na način življenja na vasi, kar po eni strani prinaša novo kakovost, po drugi strani pa različnost interesov posameznih skupin prebivalstva lahko povzroča tudi močne socialne napetosti, kar ima negativne posledice. Iz nekaterih opravljenih raziskav (npr. Perpar 2002, 134) je razvidno, da so vzroki takšnih napetosti in sporov med kmečkimi in nekmečkimi prebivalci na podeželju povezani predvsem z naravo kmetijske pridelave kot so: smrad živalskih izločkov, ropot kmetijskih strojev in naprav, delo s stroji ob poznih urah in ob nedeljah, onesnaževanje poti, mejni spori ipd.

Opuščanje kmetovanja, zmanjševanje kmetijske rabe zemljišč in zmanjševanje števila kmetij v vaseh vpliva tudi na postopno izginjanje agrarne identitete podeželskih naselij, v podeželskem prostoru pa povzročajo tudi obsežne spremembe v kulturni krajini, ki marsikje izgublja svojo nekdanjo kvaliteto in privlačnost. S tem pa nekatera območja izgubljajo tudi pomemben del svojih nekmetijskih razvojnih potencialov.

Vse omenjene težave in omejitve $\mathrm{v}$ zvezi z razvojem kmetij, prostorskimi razmerami in medsebojni odnosi med kmečkim in nekmečkim prebivalstvom v naseljih pa nenazadnje vplivajo tudi na zmanjšan interes mladih za kmetovanje.

\section{SKLEP}

Večino negativnih pojavov, ki zmanjšujejo pozitivne učinke pospešenega razvoja kmetij in podeželskih območij je mogoče odpraviti ali vsaj bistveno omiliti z bolj domišljenim načrtovanjem urejanja podeželskega prostora in podeželskih naselij ter kmetij. To načrtovanje ne sme izhajati zgolj iz načel urejanja urbanih sredin, pač pa mora nujno upoštevati sodobne zahteve kmetij in naselij ter zgodovinske, kulturne, krajinske in socialne posebnosti podeželskega prostora. Podeželska naselja morajo ohraniti svojo specifično podobo in »dušo«. Pri prostorskem načrtovanju in urejanju podeželskih naselij je potrebno še posebej paziti na to, da:

- $\quad$ se pozida in razdrobi čim manj kmetijskih zemljišč,

- da se varuje najboljša kmetijska zemljišča in za raznovrstne nujne posege v prostor išče rešitve v prvi vrsti na manj kvalitetnih zemljiščih,

- $\quad$ perspektivne kmetije niso ovirane v tehnološkem in prostorskem razvoju,

- $\quad$ se ne potencirajo socialne napetosti med kmeti in drugimi sloji prebivalstva,

- $\quad$ se ne degradira kulturne krajine in podeželski prostor ne izgubi svoje identitete.

Da bi to lahko dosegli, mora kmetijstvo v postopkih prostorskega načrtovanja sodelovati kot enakopraven partner, v postopkih pa je potrebno iskati rešitve, ki ne zasledujejo le kratkoročnih ekonomskih koristi. Z naravnimi viri nacionalnega pomena, kot so kmetijska zemljišča najboljše kakovosti, je potrebno zelo skrbno in smotrno upravljati in jih varovati. Kmetijstvo mora pripraviti ustrezne strokovne podlage ter tudi prostorsko opredeliti svojo dejavnost (opredeliti lokacije kmetij in njihova pripadajoča zemljišča, opredeliti značilna proizvodna območja ter območja najboljših kmetijskih zemljišč ipd.), kar bo pomembna informacija prostorskim planerjem pri posegih v prostor. Konflikte, ki jih prinaša večfunkcijska 
vloga prostora, je potrebno odpravljati z upoštevanjem potreb razvoja vseh dejavnosti (sektorsko planiranje) v prostoru in jih uskladiti v procesu integralnega planiranja, ki upošteva načela trajnostnega razvoja.

\section{Viri in literatura}

Cof, A. 2005: Analiza širjenja pozidanih zemljišč v Ljubljanski urbani regiji v obdobju 19512002. Seminarska naloga. Biotehniška fakulteta. Ljubljana: $31 \mathrm{~s}$.

Perpar, A. 2002: Razvojne značilnosti slovenskega podeželja. Magistrsko delo. Biotehniška fakulteta, Oddelek za agronomijo. Ljubljana: $205 \mathrm{~s}$.

Perpar, A., Kovačič M. 2006: Problematika prostorskega načrtovanja v kmetijstvu. V: Slovenija v EU - izzivi za kmetijstvo, živilstvo in podeželje. Zbornik 3. konference DAES. Društvo agrarnih ekonomistov Slovenije. Ljubljana: 81-97.

Popis kmetijskih gospodarstev, Slovenija, 2000. Ljubljana, Statistični urad RS: 256 s.

Predlog dopolnitev Zakona o kmetijskih zemljiščih. 2006. Interno gradivo Ministrstva za kmetijstvo, gozdarstvo in prehrano. Ljubljana.

Prosen, A. 1993: Sonaravno urejanje podeželskega prostora. Ljubljana, Katedra za prostorsko planiranje na Fakulteti za arhitekturo, gradbeništvo in geodezijo: $180 \mathrm{~s}$.

Prosen, A. s sod. 2005: Vrednotenje normativnega sistema varovanja kmetijskih zemljišč in opredelitev novih možnih javnih modelov. Končno poročilo projekta v okviru CRP »Konkurenčnost Slovenije 2001-2006«. Fakulteta za gradbeništvo in geodezijo - Katedra za prostorsko planiranje. Ljubljana: 11-36.

Rebernik, M. 1997: Ekonomika podjetja. 3. dopolnjena izdaja. Gospodarski vestnik. Ljubljana: s. 17.

Strategija razvoja slovenskega kmetijstva, 1993. Ministrstvo za kmetijstvo, gozdarstvo in prehrano. Ljubljana.

\section{SPATIAL ASPECTS OF FARM DEVELOPMENT}

\section{Summary}

As a rule, agriculture is not considered as a specific area or subject in spatial planning in Slovenia. Agricultural production areas are treated as open or even vacant space, available for different construction interventions. Administrative limitations were not efficient or were even reduced. Agriculture does not have the capacity to define conditions for the usage of space or to obstruct any undertakings. The reasons for this lack of ability to act include the following:

- $\quad$ Particularities of agricultural production - It does not occupy a space permanently (except for agricultural buildings), and does not cause any permanent changes in the surface structure,

- Methodology of spatial planning - following the principles of urban planning in rural space also without considering specifics of rural settlements functions. In rural and agricultural 
development, many of the agricultural holdings lose their agricultural functions, causing the rural settlements to have even more non-agricultural functions.

Different groups of problems that deter or obstruct the development of agriculture and agricultural holdings within the present system of development planning and arranging of rural settlements and space can be recognized:

- Decrease in potential resources (best agricultural land) for agricultural production,

- Spatial tightening of farms in settlements,

- Traffic isolation of farms.

Consequently, social conflicts often appear in rural settlements, rural identity of settlements and traditional cultural landscape disappears, and there is less and less interest in farming within younger generations.

\section{Decrease in Agriculture Production Potentials}

Decrease in the extent of the best agricultural land, mostly in flatlands, presents a serious obstacle for efficient improving of agrarian structure and competitiveness of Slovene agriculture. Data show a concerning decrease in the extent of agricultural land, the best quality one above all. Slovenia is already a country with one of the smallest surface of agricultural land per capita. To improve the situation and decrease the trend of building on the best agricultural land, agricultural land policy should be supplemented and implement strictly, particularly within the framework of the following measures:

- The best agricultural land must be precisely defined and also presented spatially;

- New settlement areas should be directed to areas characterised by agricultural land of lesser quality, or to the forests;

- The best agricultural areas can be used for construction interventions only when the other solutions run out in the construction of traffic, communal or social infrastructure;

- A portion of revenue from taxation on changes in land usage should be directed to funds designated for other agricultural land quality improvements;

- To limit the quantity of the best land that becomes the property of non farmers;

- To ensure evidencing of agricultural land trade.

\section{Spatial Tightening of Farms}

The term spatial tightening applies to farms that can not increase their production, modernise or increase the scope of their activities, or increase and arrange appropriately the functional area of their holdings, or apply the necessary modern machinery on their present location. Farms in settlements are often spatially tightened due to historical reasons, or because of new building ventures in their vicinity. The reasons for this problem include: Small area of the existing farm location; the owners often sell a part of their agricultural holding area or give it as a present to their descendants, who are not farmers. This process is also aided by the concept of spatial planning (principle of thickening). 
For the improvement of present situation, it would be necessary to:

- Consistently protect the best agricultural land against the changes in land usage, and to direct new settlements areas to agricultural land of lesser quality or the forests;

- $\quad$ Provide an area for displaced farm installations in spatial plans;

- $\quad$ Assess the interests and needs of farms in expanding on existing locations; in cases where new construction in the vicinity of a farm is planned, applicable laws would stipulate mandatory concession from the farm in question, and

- Lands that constitute the agricultural holding of vital farms should be preserved for permanent agricultural use, including within the defined construction areas of settlements.

\section{Traffic Induced Tightening of Farms}

The term traffic induced tightening of farms depicts farms with inadequate access to their production areas resulting from bypassing road construction (typical example is Bitnje), or from construction of new residential areas along the existing local or field traffic network (the existing network becomes a main road also for new residents), which puts an additional burden on the existing structure. In such cases, farmers have to use the public roads and, as a consequence, several problems occur: Agricultural machinery is slow and is often of extra wide dimensions, which causes problems in traffic, and also brings dirt onto the roads and causes pollution. In such cases, farmers can not avoid breaching traffic regulations, and stand at danger of traffic accidents related costs.

Some of the proposed measures for the improvement of the situation are:

- Special traffic conditions or requirements related to farms should be taken into consideration. These should include traffic infrastructure construction regulations for rural settlements and their expansion, as well as special traffic conditions and requirements for farms,

- Construction undertakings should be planned to avoid obstructing the operation of farms; farmers should not be subjected to additional costs and should not be exposed to additional danger.

- The most crucial existing problems should be resolved on basis of examples from some of the West European countries (special bypass road for agricultural machinery, paving or asphalting of field cart tracks where they join the public road, traffic signalling arrangement etc.)

\section{Social tensions in rural settlements and rural identity of settlements and agricultural landscape disappearing}

Although the changes in the structure of rural settlements (better education, diminishing of farming population and that of the number of farms, growth of the population of nonagricultural residents and their activities) and a modified way of life in the countryside had some positive effects, they also created certain social conflicts between different social groups of residents. Conflicts are mostly connected to some of the particulars of the agricultural production, such as: the stench, the noise of agricultural machinery and devices, late working 
hours that include on Sundays, public road pollution, border conflicts etc. Abandoning of farms and the decrease in the extent of agricultural land utilised consequently cause a gradual disappearing of agrarian identity of rural settlements and agricultural (cultural) landscape, along with it's quality and attractiveness. In the same process, some areas also lose an important part of their non agricultural potentials. All of the problems mentioned above also have an influence on decreasing the interest of younger generations in farming.

\section{Conclusions}

To avoid negative occurrences, the methodology of spatial planning should be improved. Agriculture must collaborate in process of spatial planning with the other users as an equal partner. Solutions shouldn't pursue only the short-term economic profits. Natural resources of national importance, such as the best agricultural land, should be managed carefully and reasonably, and should be protected to the highest possible extent. Agriculture must ensure an adequate expert basis to ensure optimal spatial planning, and corroboration and defining of the landmark terms, such as farm locations, typical production areas, areas of best quality agricultural land etc. Conflicts should be resolved with consideration for all space users and their needs for development (sectorial plans). Democratic procedures of integrated planning should be harmonized, taking into account principles of sustainable development. 